the statute no longer reflected a majority social viewpoint, there was even stronger reason to invoke the equal protection clause and enjoin admittedly discriminatory treatment. ${ }^{24}$

\title{
EXTENDING IN PERSONAM JURISDICTION BY ENFORCING STATE "BLUE SKY" LAWS AGAINST NONRESIDENTS*
}

State "Blue Sky" laws, ${ }^{1}$ by requiring the registration of securities or their sellers, ${ }^{2}$ are designed to protect the public against fraudulent or unsound investment schemes. Although criminal sanctions are generally available to

(1933) ; cf. Wade v. San Francisco, 82 Cal. App. 2d 337, 186 P.2d 181 (1947) ; sec Boyt1ton v. Fox, 60 F.2d 851, 854 (10th Cir. 1932) ; People v. Oreck, 74 Cal. App. 2d 215, 221, 168 P.2d 186, 190 (1946) ; People v. Darcy, 59 Cal. App. 2d 342, 354, 139 P.2d 118, 126 (1943). But see Creash v. State, 131 Fla. 111, 121, 179 So. 149, 153 (1938) ("If such favoritism exists, the polls rather than the Court would be the proper forum to correct it."). See also cases cited note 18 sipra.

On the other hand, failure to extend the equal protection clause to cascs of discriminatory law enforcement gives local police officials unlimited power to conduct prosecutions based on racial, ideological, or political prejudice. See, for example, Jackie Cab Co. v. Chicago Park Dist., 366 I11. 474, 9 N.E.2d 213 (1937) (discrimination against Negroes); People v. Darcy, supra (discrimination against Communist). See also the allegation of political prejudice by the Society of Good Neighbors, stipra note 7. For a strong denunciation of thus placing a Damoclean sword in the hands of local police officials, sce People v. Darcy, supra at 360,139 P.2d at 129: "It is much better for society that an accused should go free, than for our criminal processes to be polluted by prosecutions founded on prejudice against and hatred for the political beliefs of the accused."

24. See notes 6 and 20 supra.

* Travelers Health Ass'n v. Commonwealth of Virginia, 188 Va. 877, 51 S.E. $2 \mathrm{~d} 263$ (1949), probable jurisdiction noted, 17 U.S.L. WEEK 3365 (U.S. June 14, 1949).

1. The name given to these laws indicates their purpose-preventing "speculative schemes which have no more basis than so many feet of "blue sky." "Hall v. GeigerJones Co., 242 U.S. 539, 550 (1917) (upholding constitutionality of Blue Sky laws).

2. All the states except Nevada have legislation regulating offers to sell or sales of securities. All but two require some sort of registration:

(1) The "fraud" type of law requires neither licensing of distributors nor registration of securities; it merely prescribes penalties for fraud and authorizes injunctive proceedings to prevent frauds. Providing for the least regulatory detail, this type statute exists in only two states. DeL. REv. Code $\$ 4369$ (1935); N. J. STAT. ANN. $\$ \$ 49: 1-1$ to $49: 1-29$ (1940). The New York "Martin Act," N.Y. GEN. Bus. LAw $\$ \$ 352$ to 359-h, though purporting to be chiefly a "fraud" law, requires that dealers file certain statements and notices with state officials. In effect, this modified "fraud" law provides for the licensing of dealers. See Smith, State "Blue Sky" Lazes and the Federal Securitics Acts, 34 MiCH. L. REv. 1135, 1137 n.8 (1936).

(2) The "licensing" type controls the distribution of securities by requiring distributors to be licensed. E.g., ME REv. Stat. c.55, § 208 (1944).

(3) The "inspection" type statute provides for the registration of securities that are 
compel registration, ${ }^{3}$ state officials prefer a more effective remedy-an injunction against the sale of unregistered securities. Before an injunction may issue, however, due process demands that in personain jurisdiction be obtained over the defendant.5 This jurisdictional requirement may be satisfied by

to be sold in the state but does not require that their distributors be licensed. E.g., N. M. STAT. ANN. \$\$ 50-1701 to 50-1715 (1941).

(4) The most common type of statute, a combination "licensing and inspection" 13w, requires both the licensing of distributors and the registration of securities. E.g., MO. Rev. Stat. ANN. \$\$ \$258-\$292 (1943). See Smith, supra, at 1137, 1138.

For a concise, over-all summary of how state Blue Sky acts generally operate, sce 1 CCH Blue Sky Law Rep. Iff 503-51S (1946). For their history and purpose, see ReEd \& WashburN, Blue SEy Laws ix-xviii (1921).

Where securities enter interstate commerce, the states must share the regulatory function with the Federal Government. 48 STAT. 74-92 (1933), 15 U.S.C. \&\$ 773-77a3 (1946) (Securities Act of 1933) ; 4S STAT. $\$ 81$ (1934), 15 U.S.C. $\$ 783$ (1946) (Securities Exchange Act of 1934). It is clear that these federal acts do not supersede state provisions which are not conflicting. 48 STAT. 85 (1933), 15 U.S.C. \$77r (1946). Federal acts are confined to the prevention of fraud by requiring full disclosure of the facts relating to issues and by making unlawful the use of the mails or instrumentalities of interstate commerce to defraud. See Hanna, The Sccuritics Exchasge Aet as Supplcmentary of the Securities Act, 4 LAw \& ConTearp. Prob. 256 (1937); MracChesney and O'Brien, Full Disclosure Under the Securities Act, 4 Law \& Conresrp. Prob. 133 (1937). State acts, on the other hand, generally give the investing public additional protection by passing upon the "soundness" of securities. E.g., IND. Axr. STAr. \$25-\$36 (Burns 1933) (Securities Commission can deny registration if business of issuer is "based upon unsound business principles"). See Wright, Correlation of State Bluc Sty Laus and the Federal Securities Acts, 26 CoRnenr L.Q. 258, 261, 262 (1941), where practical methods are suggested for integrating the various state and federal laws so that burdens on interstate issues may be eliminated.

3. For a compilation of the laws by states, see $1 \& 2$ CCH Blog SKY Law Rep. (1946).

4. In addition to speed and prevention, administrative preference for using the injunctive method may stem from a belief that lay juries are not qualified to deal with questions relating to securities transactions. Mroreover, in the absence of actual fraud, administrators would rather secure compliance than impose criminal penalties. Communication to the YaIE Law Journal from William C. King, Direetor of the Virginia State Corporation Commission, October 10, 1949.

Every Blue Sky law provides for injunctive proceedings against violators. See 1 \& 2 CCH BLUE SKY LAW REP. (1948). In some states, securities commissions may themselves issue injunctive-type cease and desist orders. E.g., VA. COrE Awr. \$3848 (52) (1942). In others, they must resort to the appropriate courts for injunctions. E.g., Tex. Crv. Stat. art. 600a, \$ 33 (Vernon 1942).

For a general evaluation of the injunction as an enforcement device, see Comment, 57 YaLe L. J. 1023 (1948). See also Mialoney, Injunctize Law Enforccment, 1 Afercen L. REv. 1 (1949).

5. Pennoyer v. Neff, 95 U.S. 714 (1877) ; Burdick, Scrcice as a Requirenent of Dise Process in Actions in Personam, 20 Ifrcr. L. Rev. 422 (1922) ("A prime requisite of due process is; of course, that the court shall have jurisdiction of the subject-matter. . . . In proceedings in personam-proceedings to determine the personal liability of the defendant, no property being brought by the proceedings within the control of the courtthe court must also have jurisdiction of the defendant.").

Although injunctive-type proceedings are typically classified as in personom, suits 
personal service when such suits are brought against nonresidents physically present within the state. ${ }^{6}$ But where the nonresident is absent, the inability to serve him personally subjects the state's jurisdiction to attack on due process grounds. ${ }^{\top}$

Virginia successfully met such an attack in Travelers Health Ass' $n$ v. Commonwealth of Virginia. ${ }^{8}$ Travelers, a nonprofit health corporation domiciled in Nebraska, sold membership certificates ${ }^{0}$ by mail to Virginia residents without registering under the state Blue Sky law. It solicited these new memberships by written invitations mailed to persons recommended by its Virginia members. ${ }^{10}$ The state Corporation Commission, relying on registered mail service to sustain personal jurisdiction over the absent corporation, issued a cease and desist order enjoining the sale of the securities. ${ }^{11}$

Appealing from the cease and desist order, the defendant corporation con-

to enjoin the sale of unregulated securities might be categorized as actions in rem. The proceeding would then be against the entering securities as property brought within the jurisdiction of the court and not against the defendant personally. Wilentz v. Edwards, 134 N.J. Eq. 522, 36 A.2d 423 (Ct. Err. \& App. 1944) semble. But such a shift in cate* gories is made unnecessary by the liberal interpretation of in persontan jurisdiction in International Shoe Co. v. Washington, 326 U.S. 310 (1945). See note 14 infra.

6. Pennoyer v. Neff, 95 U.S. 714 (1877).

7. See Burdick, supra note 5, passim. That the attack is frequently made does not signal its success. In fact, there has been a widening area in which states have been permitted to obtain in personam jurisdiction over absent nonresidents. Thus, a nonresident motorist by using the state's highways may be bound by statute to defend in that "state a suit growing out of an accident there. In such cases, due process is satisfied if the statute affords reasonable probability of notice and allows reasonable opportunity to defend. Hess v. Pawloski, 274 U.S. 352 (1927). See 2 Moore, Federal Practice if 4.16 (1948) ; Culp, Recent Developments in Actions Against Nonresident Motorists, 37 Micu. L. REv. 58 (1938); Scott, Jurisdiction Over Nonresident Motorists, 39 HARv. L. Rev. 563 (1926). Similarly, an absent nonresident individual who sells securities through a branch office may be subjected to that state's personal jurisdiction if the cause of action arises out of such sales. Fenry L. Doherty \& Co. v. Goodman, 294 U.S. 623 (1935). See 2 Moore, Federal Practice $\int 4.17$ (1948); Daum, The Transaction of Busincss Within a State by a Non-Resident as a Foundation for Jurisdiction, 19 Iowa L. REv. 421 (1934). Where the nonresident is a corporation, a given quantity and quality of business activity within a state may render the corporation amenable to that state's in pcrsonam jurisdiction. For a general discussion of the activities that constitute "doing business" in a state for purpose of subjection to suit there, where a corporation has not expressly appointed an agent to receive service of process, see 2 Moore, Federal PracticE $\llbracket 4.25$ (1948); Note, The Growth of the International Shoe Doctrine, 16 U. of Crir. L. REv. 523 (1949).

8. 188 Va. 877, 51 S.E.2d 263 (1949), probable jurisdiction noted, 17 U.S.L.WEEK 3365 (U.S. June 14, 1949).

9. This type of security is exempt from federal regulation. See 48 StAт, 881 (1933), 15 U.S.C. $\$ 77 \mathrm{c}(8)(1946)$.

10. Transcript of Record, p. 2, Travelers Health Ass'n y. Commonwealth of Virginia, 188 Va. 877,51 S.E.2d 263 (1949).

11. Id. at 27. Service was obtained under VA. CODE ANN. §3848(52) (1942): Where service cannot be had on persons or corporations because the securities are offered by "periodicals, mail, telephone, telegraph, radio, or other means of communication from 
tested the constitutionality of the Blue Sky statute's jurisdictional provision.12 It recognized that International Shoe Co. v. Washington, ${ }^{13}$ the latest Supreme Court test for in personam jurisdiction over nonresidents, required only such "minimum contacts" as would prevent the suit from offending "traditional notions of fair play and substantial justice."14 But the corporation, relying on the earlier case of Mimnesota Commercial Mcn's Ass' $v$. Bcm, in insisted that International Shoe still demanded the presence of authorized agents within

beyond the limits of the State," jurisdiction in an injunctive proceeding may be obtained "through the medium of at least 10 days' notice ... by registered mail, return receipt demanded."

12. VA. CoDE ANN. $§ 3848(52)$ (1942), supra note 11. The defendant maintained that the section was unconstitutional in so far as it purported to "authorize the issue of an in personam decree against ... a foreign corporation not domiciled, domesticated or doing business in this state, on substituted service of process." Brief for Appellants, p. 33, Travelers Health Ass'n v. Commonwealth of Virginia, 188 Va. 877, 51 S.E.2d 263 (1949). See note 7 supra.

It also argued that Virginia's attempt to regulate the securities sold by mail was an unconstitutional regulation of the United States mail. Brief for Appellants, sipro, at 46. But this argument is wholly without merit. Congress has given the states permission to exercise concurrent jurisdiction in regulating the interstate sale of securities. See 48 Stat. 85 (1933), 15 U.S.C. \$77r (1946). See Merrick v. N.W.Halsey \& Co., 242 U.S. 568 (1917), infra note 18.

13. 326 U.S. 310 (1945). See note 14 infra.

14. International Shoe Co. v. Washington, 326 U.S. 310, 316 (1945). The case involved a suit by Washington to recover unemployment compensation contributions allegedly due from a foreign corporation. The corporation's contact with the state was through several salesmen who resided there. Their authority was limited to exhibiting samples and soliciting orders at prices and on terms fixed by the corporation; no salesman had authority to enter into contracts or to make collections. In personam jurisdiction over the corporation was secured by personal service upon one of these salesmen, coupled with registered-mail notice to the corporation at its principal place of business in St. Louis, Mfissouri. In affirming a judgment in favor of the state, the Supreme Court elaborated on its "fair play" rule:

"To say that the corporation is so far 'present' there [in Washington] as to satisfy" due process requirements ... is to beg the question to be decided. For the terms 'present' or 'presence' are used merely to symbolize those activities of the corporation's agent within the state which courts will deem to be sufficient to satisfy the demands of due process. ... Those demands may be met by such contacts of the corporation with the state of the forum as make it reasonable in the contest of our federal system of government, to require the corporation to defend the particular suit which is brought there. An 'estimate of the inconveniences' which would result to the corporation from a trial away from its 'home' or principal place of business is relevant in this connection. ..." Id. at 316-17.

"The activities carried on in behalf of appellant in the state of Washington . . . vere systematic and continuous. . . . The obligation which is here sued upon arose out of those very activities. ... [T] [Tese operations establish sufficient contacts or ties with the state of the forum to make it reasonable and just, according to our traditional conception of fair play and substantial justice, to permit the state to enforce the obligations which appellant has incurred there" Id. at 320 .

15. 261 U.S. 140 (1923). See note 17 infra. 
the state.16 In the Benn case, the Supreme Court held that mail order sales by a nonresident health insurance corporation to customers residing in Montana did not subject that corporation to Montana's in personam jurisdiction. Solicitation of customers was by members residing in Montana who were not agents of the corporation. ${ }^{17}$ These factual similarities to the Travelers' practices enabled it to argue that the $B e n n$ case controlled here.

But the Supreme Court of Virginia held that the Benn case was not controlling. While it might have done so by recognizing that International Shoc in effect overruled $B e n n,{ }^{18}$ the court chose instead to distingtish the case on its facts. In Benn, an individual was suing a foreign corporation on an insurance contract to obtain a money judgment; here, the state was conducting an inquiry, "quasi-criminal in its approach," to determine whether the activities of a foreign corporation should be enjoined as violations of its Blue Sky law. ${ }^{19}$ And, since Section 6 of Nebraska's Extradition Act ${ }^{20}$ enables Virginin

16. Brief for Appellants, p. 23, Travelers Health Ass'n v. Commonwealth of Virginia, 188 Va. 877, 51 S.E.2d 263 (1949). International Shoe did not explicitly overrule the Bemn case. See International Shoe Co. v. Washington, 326 U. S. 310,319 (1945). Moreover, International Shoe itself involved corporate agents physically present within the state. The defendant cited the case at 326 U. S. 310, 316-17 (1945), where the Supreme Court, discussing the fiction of corporate presence, said: "For the terms "prcscil" or 'presence' are used merely to symbolize those activities of the corporation's agent within the state which courts will deem to be sufficient to satisfy the demands of due process. ..." (emphasis supplied by defendant). See note 14 supra.

17. "[I]t cannot be said that the Association was doing business in Montana merely because ... members, without authority to obligate it, solicited new members. That is not enough 'to warrant the inference that the corporation has subjected itself to the local jurisdiction, and is by its duly authorized officers or agents present within the state or district where service is attempted.'" Minnesota Commercial Men's Ass'n v. Benn, 261 U.S. 140, 145 (1923).

18. The Supreme Court in Bemm relied on the "mere solicitation rule" to determine that the corporation was not "doing business" in the state for purposes of the suit in question. But the "rule"-that solicitation alone, without other activities on the part of the agents within the state is not "doing business," Green v. Chicago, Burlington \& Quincy Ry., 205 U.S. 530 (1907) - has been emasculated by the "fair play" approach of Intcrnational Shoe, at least where the cause of action arises out of the solicitation. International Shoe Co. v. Washington, 326 U.S. 310, 319 (1945) ; cf. Storey v. Unitcd Insurance Co., 64 F.Supp. 896 (E.D.S.C. 1946) (upholding statutory substituted service on a foreign corporation soliciting insurance by mail where cause of action arose out of such activity). But cf. Cindrich v. Indiana Travelers Assur. Co., 356 Mo. 1064, 204 S.W.2d 765 (1947) (in a similar case, a similar statute held not to apply to insurer's transactions in light of the Bern case, the court never mentioning International Shoe).

19. "The proceeding before us ... is essentially different in its nature. It was instituted, not by a contract holder, but by the Commonwealth. The appellants were being investigated by the Commission to determine whether their activities did in fact violate the Securities Act and constitute the commission in Virginia of a misdeameanor. The inquiry is quasi-criminal in its approach." Travelers Health Ass'n v. Commonwealth of Virginia, 188 Va. 877, 889, 51S.E.2d 263, 267 (1949).

The court relied for this distinction on Merrick v. N.W.Halsey \& Co., 242 U.S. 568 (1917). But the Merrick case certainly does not authorize in personam jurisdiction over an absent nonresident criminally accused. There the nonresident party engaging in the 
to extradite for past violations originating in Nebraska, Virginia should not be precluded from bringing civil suit in its own courts to enjoin the defendant's future violations. The court concluded, therefore, that the "fair play" requirement of International Shoe was met by actual notice to the defendant.21

While the court's quasi-criminal approach serves to prevent the Blue Sly violation in this case, its application in similar cases might prove unreliable. Where nonresidents sell securities through the mail, the court's reasoning rules out prohibition of Blue Sky evasion if the enforcing state provides no criminal sanction for such violations. ${ }^{22}$ Nor can evasion be enjoined if the seller's state has not adopted Section 6 of the Uniform Extradition Act or its equivalent. ${ }^{23}$ Hence, the court's rationale makes the successful enforcement of Blue Sky laws depend on the availability of extradition process, a factor bearing no relationship to protecting the state's residents from unregulated securities.

If the Blue Sky laws and similar protective statutes of the various states are to be made effective against distant evasion, the strict territorial notion of in personam jurisdiction should be frankly and completely abandoned.:Since economic activities transcend state borders, a far more appropriate definition of jurisdiction is the equitable notion of "fair play" announced in Inter-

mail-order sale of securities, a partnership, was only one of many parties seeling an injunction against enforcement of the Mlichigan Blue Sky law. The others included forcign corporations with agents in Mfichigan who solicited orders or sold capital stock directly. Nowhere in the opinion itself, after the initial statement of facts, did the Supreme Court advert to the situation as to the nonresident partnership or say specifically that the statute did or did not apply to it. Nevertheless, the Mrichigan officials were left free to enforce the state Blue Sky law against all parties, including the partnership. "The only saic interpretation to put upon this phase of the opinion is that the state may prohibit and make criminal a particular act, i.e. an offering or sale, effected 'within the state'

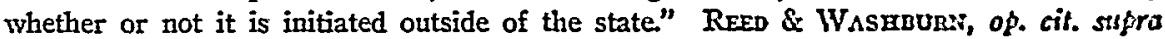
note 2 , at $262 \mathrm{a}$.

Hence, it is not safe to say, as did the court in Travelers Health, that the Mfcricle case established any distinction for purposes of in personam jurisdiction between ordinary acts and acts violating state laws.

20. NEB. RET. StAT. \$29-706 (1943), which authorizes the Governor of Nebraslas to grant extradition when crimes are committed in another state, even though the accused is not a fugitive from that other state. This is Section 6 of the Uniform Extradition Act. Interstate Connatssion on Crnare, Handbook on Interstate Crrege Conimol 11 (1949).

21. "Nor do we think the proceedings ... offend "traditional notions of fair play and substantial justice'. . . The Commission might have undertaken to proceed against the appellants by information or indictment and extradition. The present proceeding is a very much less onerous one." Travelers Health Ass'n v. Virginia, 183 Va. 877, 896, 51 S.E. $2 d 263,271$ (1949).

22. Every state makes it a crime to violate its Blue Sly laws except Delaware. See DEt. REv. CODE $\$ 4369$ (1935).

23. See note 20 supra. The substance of Section 6 has been adopted in thirty-two states and Hawaii. See 9 UNIF. L. ANN. 169 (1942); id. at 30 (Cum. Annual Pocket Pt. 1948).

24. See note 7 supra. 
national Shoe, which merely asks whether it is reasonable, in the light of what the nonresident is doing in the forum state, to maintain an action against him there. ${ }^{25}$

The "fair play" test involves a balancing of conflicting interests when ap)plied to contract, tort and similar actions against nonresidents by individuals or by states acting in an individual capacity. ${ }^{20}$ In those situations, therefore, it is vague and unpredictable. ${ }^{27}$ But where the state as a sovereign seeks to protect its citizenry, as in the Travelers Health case, its paramount right to enforce its laws in its own courts outweighs any burdens imposed on the nonresident. Here the "fair play" test reduces to the simple and fairly predictable formula of "notice" to the absent offender. Reasonable probability of actual notice, which a registered letter usually provides, meets the requirement of

25. "Whether due process is satisfied must depend . . . upon the quality and nature of the activity in relation to the fair and orderly administration of the laws which it was the purpose of the due process clause to insure." International Shoe Co. v. Washington, 326 U.S. 310,319 (1945).

So, for example, the defendant's activities in International Shoc were "systematic and continuous" and gave rise to the liabilities sued on. Such activities, establishing the defendant's relationship with the state of the forum, made it "reasonable and just, according to our traditional conception of fair play and substantial justice, to permit the state to enforce the obligation . . . incurred there." Id. at 320.

Actually, the holding in International Shoe was not a radical departure from prior cases-it merely discarded the fictions of corporate "presence" formerly resorted to by the courts. See Note, The Grozoth of the International Shoe Doctrine, $16 \mathrm{U}$. of Crrr. L. REv. 523, 524 (1949). The extent and quality of the activities of a forcign corporation within the forum state were always significant in determining whether the corporation was doing such business in the state as to warrant the inference that it was "present" for the purpose of defending the suit in question. Where courts held, as in Minncsota Commercial Men's Ass'n v. Benn, 261 U.S. 140 (1923), supra note 17, that a corporation was not "doing business" in the state, the statement meant that the corporation's activities were not so extensive as to make it reasonable to require it to defend there. Sce 2 Moore, Federal Practice $\llbracket 4.25$ (1948).

While International Shoe involved a nonresident corporation, everything said there is applicable to individuals as well. See Note, 16 U. of Crr. L. REv. 523, 534 (1949). See generally, Scott, Jurisdiction Over Nonresidents Doing Business Within a Siate, 32 HARv. L. REv. 871, 888-9 (1919); Daum, supra note 7, at 431.

26. According to Judge Learned Hand, whose reasoning in a prior case was relied on considerably in International Shoe, the latter case held that in order to determine jurisdiction "the court must balance the conficting interests involved: i.e., whether the gain to the plaintiff in retaining the action where it was, outweighed the burden imposed upon the defendant; or vice versa." Kilpatrick v. Texas \& P. Ry. Co., 166 F.2d 788, 790, 791 (2d Cir. 1948), cert. dentied, 335 U.S. 814 (1948).

27. See McBaine, Jutrisdiction Over Foreign Corporations: Actions Arising Out of Acts Done Within the Forum, 34 Calif. L. Rev. 331, 336 (1946), where the test of International Shoe is criticized as being no less vague and uncertain than the "presence" theory which it abandoned. See note 14 stpra. For cases applying the "presence" theory, see Bank of America v. Whitney Cent. Nat. Bank, 261 U.S. 171 (1923); People's To* bacco Co. v. American Tobacco Co., 246 U.S. 79 (1918) ; International Harvester Co. v. Kentucky, 234 U.S. 579 (1914). 